\title{
Early Diagnosis and Screening for Lung Cancer
}

\author{
Humam Kadara, ${ }_{1}^{1}$ Linh M. Tran, ${ }^{2}$ Bin Liu, ${ }^{2}$ Anil Vachani, ${ }^{3}$ Shuo Li, ${ }^{4}$ Ansam Sinjab, ${ }^{1}$ \\ Xianghong J. Zhou, ${ }^{4}$ Steven M. Dubinett, $2,4,5,6,7$ and Kostyantyn Krysan ${ }^{2,7}$ \\ ${ }^{1}$ Department of Translational Molecular Pathology, University of Texas MD Anderson Cancer Center, \\ Houston, Texas 77030, USA \\ ${ }^{2}$ Department of Medicine, David Geffen School of Medicine at UCLA, Los Angeles, California 90095, USA \\ ${ }^{3}$ Pulmonary, Allergy, and Critical Care Division, Department of Medicine, University of Pennsylvania \\ and Philadelphia VA Medical Center, Philadelphia, Pennsylvania 19104, USA \\ ${ }^{4}$ Department of Pathology and Laboratory Medicine, David Geffen School of Medicine at UCLA, \\ Los Angeles, California 90095, USA \\ ${ }^{5}$ Department of Molecular and Medical Pharmacology, David Geffen School of Medicine at UCLA, \\ Los Angeles, California 90095, USA \\ ${ }^{6}$ UCLA Jonsson Comprehensive Cancer Center, Los Angeles, California 90024, USA \\ ${ }^{7}$ VA Greater Los Angeles Healthcare System, Los Angeles, California 90073, USA \\ Correspondence: SDubinett@mednet.ucla.edu; KKrysan@mednet.ucla.edu
}

Cancer interception refers to actively blocking the cancer development process by preventing progression of premalignancy to invasive disease. The rate-limiting steps for effective lung cancer interception are the incomplete understanding of the earliest molecular events associated with lung carcinogenesis, the lack of preclinical models of pulmonary premalignancy, and the challenge of developing highly sensitive and specific methods for early detection. Recent advances in cancer interception are facilitated by developments in next-generation sequencing, computational methodologies, as well as the renewed emphasis in precision medicine and immuno-oncology. This review summarizes the current state of knowledge in the areas of molecular abnormalities in lung cancer continuum, preclinical human models of lung cancer pathogenesis, and the advances in early lung cancer diagnostics.

\section{MOLECULAR ABNORMALITIES FOUND IN PRENEOPLASIA AND LUNG EPITHELIUM AT RISK}

haracterizing cellular, molecular, and genetic abnormalities has been crucial to our understanding of lung tumor biology, as well as in guiding investigations of prognostic and predic- tive markers for the various subtypes of lung cancer. The advent of advanced molecular analysis tools, such as sequencing and proteomics, is enabling identification of potential markers for lung cancer detection at its earliest stages, including pulmonary preneoplastic lesions. This facilitates the effort to drive clinical management toward molecular-based and personalized

Editors: Christine M. Lovly, David P. Carbone, and John D. Minna

Additional Perspectives on Lung Cancer: Disease Biology and Its Potential for Clinical Translation available at www.perspectivesinmedicine.org

Copyright (C) 2021 Cold Spring Harbor Laboratory Press; all rights reserved; doi: 10.1101/cshperspect.a037994 Cite this article as Cold Spring Harb Perspect Med 2021;11:a037994 
H. Kadara et al.

targeted therapies. For example, a progressive mutational evolutionary model has been described for non-small-cell lung cancer (NSCLC) by identifying different branches of mutations using a deep sequencing approach, which may explain the temporal diversity during tumor progression (de Bruin et al. 2014; Anichini et al. 2018). Although extensive research has focused on intrinsic tumor cell abnormalities, including activated oncogenes or deactivated tumor suppressor genes, more recent attention focuses on cancer cells that are dynamically recruiting stromal, vascular, and immune cells, which in turn secrete signals and metabolites that can further promote tumor cell proliferation and immune evasion. Reciprocal interaction between developing premalignant cells and the microenvironment can modulate various steps of tumor pathogenesis, including known preneoplastic molecular events. Our overall understanding of the earliest molecular alterations in preneoplasia, in the context of the microenvironment, is vital for the eventual development of clinical interception that seeks to prevent invasive disease (Blackburn 2011; Spira et al. 2017). This section summarizes the state of knowledge of the molecular, genetic, and epigenetic changes occurring in the earliest known lesions of lung cancer. Further, exploration of the molecular aberrations of the lung "field of injury" in the cytologically normal airway, including oncogenic mutations (Kadara et al. 2019) and gene expression changes, described in further detail below, are also considered as key modulations for early pathogenesis and may be highly significant for the detection of malignancy.

\section{KRAS Mutations}

KRAS codon 12 mutations have been reported to be present in $30 \%$ to $40 \%$ of atypical adenomatous hyperplasias (AAHs) as well as in $24 \%$ to $50 \%$ of invasive lung adenocarcinomas (LUADs) (Westra et al. 1993). However, due to differences in reported base substitution patterns between $\mathrm{AAH}$ lesions and their respective advanced LUADs, it is plausible to surmise that AAHs and LUADs may arise independently (Westra et al. 1993; Kitamura et al. 1999). In a cohort of
AAHs and paired LUADs, KRAS-mutant AAHs were typical of ever-smokers and progressed to LUADs with additional driver mutations, such as TP53, EGFR, and KRAS, as inferred from the matched LUADs (Sivakumar et al. 2017).

\section{BRAF Mutations}

In two separate cohorts investigating AAHs and matched LUADs, the majority of AAHs displayed $B R A F$ oncogene mutations (Izumchenko et al. 2015; Sivakumar et al. 2017). In one cohort, four AAHs harbored BRAF K601E mutation; one had BRAF N581S mutation, with 4/5 displaying additional driver mutations in EGFR, rather than $B R A F$, in their paired LUADs (Sivakumar et al. 2017). This may explain the low frequency of $B R A F$ mutations in invasive LUADs (Izumchenko et al. 2015). BRAF-mutant AAHs were detected in both nonsmokers and ever-smokers (Sivakumar et al. 2017). Additionally, BRAF and KRAS mutations showed mutual exclusivity in AAHs and seemed to have undertaken divergent pathogenic pathways leading to LUADs (Sivakumar et al. 2017).

\section{EGFR Mutations}

AAHs could also be driven by EGFR mutations, namely, in-frame deletions of exon 19 and L858R and L861Q substitutions in exon 21, both of which also exist with increasing frequency throughout histological progression to more advanced adenocarcinoma in situ (AIS) lesions as well as LUADs (Yatabe 2010). Unlike their mutually exclusive counterparts (KRAS-mutant AAHs), EGFR-mutant AAHs are not associated with smoking status (Kadara et al. 2016). However, similar to KRAS-mutant AAHs but unlike $B R A F$-mutant AAHs, EGFR shares the exact mutation in both AAHs and matched LUADs (Izumchenko et al. 2015; Sivakumar et al. 2017).

\section{TP53 Mutations}

TP53 mutations are among the well-studied lung preneoplastic molecular aberrations, which affect nearly half of all lung cancers (Rom et al. 2000). A missense mutation causes the protein 
to lose its DNA binding activity due to a change in a single amino acid residue. The result is a loss of wild-type p53 activity as a regulator of genetic instability, leading to an accumulation of further genetic mutations and a cascade of oncogenic functions (Sigal and Rotter 2000). Nuclear accumulation of $\mathrm{p} 53$ has also been shown to be an early event in lung carcinogenesis with the potential to identify smokers who are at risk of developing lung squamous cell carcinoma (LUSC), albeit not in the estimation of survival (Piyathilake et al. 2003). While p53 aberrations have been reported as a widespread phenomenon in lung cancer, their extent varies across different lung cancer subtypes, and may change with tumor progression, as inferred from studies investigating preneoplastic lesions. For instance, while $33 \%$ of LUADs are reported to have p53 alterations (a low frequency in comparison to $70 \%$ in small-cell undifferentiated carcinoma, $47 \%$ in NSCLC, $65 \%$ in LUSC, $60 \%$ in large cell carcinoma), their precursors, AAHs, rarely display mutations of the $p 53$ gene.

The dynamics of the mutational events during the progression from pulmonary premalignancy to invasive disease has recently begun to be more completely understood. A recent study demonstrated an increase in the number of mutations in oncogenes and tumor suppressor genes with progression from $\mathrm{AAH}$ to invasive LUAD, whereas the overall mutational load did not significantly change (Krysan et al. 2019). On the contrary, another study reported a progressive increase of the total mutational burden, as well as the rate of chromosomal abnormalities, from AAH to AIS, minimally invasive adenocarcinoma (MIA), and ADC (Hu et al. 2019). Furthermore, the frequency of p53 mutations was shown to increase as AAHs progress to MIA, AIS, and invasive LUADs (Izumchenko et al. 2015; Sivakumar et al. 2017; Chen et al. 2019). Additional studies are needed to dissect the genomic evolution in the lung cancer continuum in the context of both genes and pathway deregulation.

\section{CHROMOSOMAL ABNORMALITIES}

Loss of heterozygosity (LOH) has been described as an early event in carcinogenesis across several lung cancer subtypes whereby focal chromosomal losses are commonly identified in multiple lung precursor lesions. In $\mathrm{AAH}$, $\mathrm{LOH}$ in chromosomal regions $3 \mathrm{p}$ (FHIT gene, $18 \%$ of AAHs), $9 p$ ( $p 16$ gene, $13 \%$ of AAHs), $9 q$ (tuberous sclerosis complex 1[TSC1]), 17q, and 17p (TP53) has been well described (Takamochi et al. 2001; Wistuba and Gazdar 2006), whereby both $3 p$ and $9 p$ represent loci altered in LUADs, albeit more frequently than in their respective precursors (Chmara et al. 2004). In preinvasive bronchial epithelium lesions of LUSC, multiple early allelic losses in 3p (3p21, 3p14, 3p22-24, and $3 \mathrm{p} 12$ ) are followed by $\mathrm{LOH}$ at $9 \mathrm{p} 21$ (Wistuba et al. 1999, 2000). Interestingly, $\mathrm{LOH}$ is detected in histologically normal bronchial mucosa of smokers, indicating that it is an early genetic aberration caused by smoking-induced damage, despite having no correlation with increased risk for development of invasive carcinoma (Wistuba et al. 1997). Allelic imbalance has been also reported in preinvasive lesions of LUSC, such as events affecting 8p21-23, 13q14 (RB1), and 17p13 (TP53) loci (Wistuba et al. 1999).

\section{SOX2 Alterations}

Amplification of distal 3q has been shown to be an early genetic event in LUSC carcinogenesis as detected in high-grade bronchial dysplastic lesions (McCaughan et al. 2010; Yuan et al. 2010). The modification translates to amplification of the SOX2 gene, which is in fact known to be amplified in LUSC of not only the lung ( $20 \%$ ) but also esophagus, cervix uteri, skin, and penis (Hussenet et al. 2010). SOX2 has been also investigated at the expression level in early LUSC where it is frequently expressed (Mukhopadhyay et al. 2014) as well as being overexpressed in $60 \%-90 \%$ of LUSC, further suggesting a potential role for this genetic modulation in initiation of LUSC particularly in light of its known role as a mediator in lung cancer stem cell self-renewal (Bass et al. 2009; Lu et al. 2010; Xiang et al. 2011). In LUAD pathogenesis, however, SOX2 expression seems to be completely lost (Yuan et al. 2010). 
H. Kadara et al.

\section{P16 ${ }^{I N K 4 A}$ Aberrations}

Loss of $\mathrm{p} 16^{\mathrm{INK} 4 \mathrm{~A}}$ protein expression has been well documented in early stages of NSCLC whereby the CDKN2A ( $\left.p 16^{\text {Ink4a }}\right) / A R F$ locus at 9 p21 was shown to be aberrantly methylated. This was also reported in precursor lesions of LUSC, whereby methylation of $p 16^{\text {Ink } 4 a}$ was demonstrated in $75 \%$ of carcinoma in situ (CIS) that is adjacent to invasive LUSC. Methylation of the CDKN2A promoter showed increasing frequencies during progression of LUSC from basal cell hyperplasia ( $17 \%$ methylation) to squamous metaplasia (24\%) to CIS and invasive carcinoma (50\%-75\%) (Belinsky et al. 2002; Lamy et al. 2002).

\section{OTHER DEVIATIONS IN LUNG PRENEOPLASTIC BIOLOGY}

Frequent $A K T$ activation has been reported in a number of advanced cancers, including lung tumors (Tichelaar et al. 2005). AKT hyperactivation is mediated by the increased expression of its phosphorylated form. AKT phosphorylation and activation of downstream signaling pathways may represent an early event in lung cancer progression, based on evidence from preneoplastic lesions such as bronchial dysplasia and preneoplastic and preinvasive bronchial lesions from patients with a long history of smoking, and, in some cases, a high risk of NSCLC recurrence (Tsao et al. 2003). These studies suggest that targeting preneoplastic lesions in individuals with high risk of lung cancer and activated AKT signaling, using PI3K/AKT pathway inhibitors, may be a promising approach to chemoprevention due to the early manifestation of this activated signaling pathway (Tsao et al. 2003; Balsara et al. 2004).

Further aberrations have been described in AAHs, such as increased expression of the oncogenes coding for cyclin D1, survivin, and ERBB2 (Westra 2000; Nakanishi et al. 2003; Tominaga et al. 2003), down-regulation of the tumor suppressor gene $L K B 1$ also known as STK11 (Ghaffar et al. 2003), increased expression of NKX2-1 also known as TTF-1 (Yatabe et al. 2002) in AAHs as well as AIS, and elevated reactive oxygen species expression (Bonner et al. 2004). Bronchial premalignant lesions, precursors of LUSC, have been also reported to harbor elevated levels of VEGF and VEGFR, aberrant patterns of microvascularization (Keith et al. 2000; Hirsch et al. 2001; Merrick et al. 2005). There is a linear increase in proliferation and DNA repair at the earliest molecular transformation changes and up to invasive LUSC (Beane et al. 2019; Mascaux et al. 2019). There is also a transitory increase in metabolism genes (fatty acid metabolism, oxidative phosphorylation, and the citric acid cycle) (Mascaux et al. 2019).

Recent studies have explored a potential role for the immune microenvironment in neoplastic progression in the lung. One study demonstrated that an increased number of neoantigens produced by the mutated genes in $\mathrm{AAH}$ lesions promoted $\mathrm{CD}^{+} \mathrm{T}$ cell infiltration (Krysan et al. 2019). Furthermore, the overall neoantigen load in $\mathrm{AAH}$ positively correlated with $\mathrm{CD} 4^{+} \mathrm{T}$-cell infiltration and PD-L1 expression. In another study, sets of normal AAH and LUAD tissues were collected and interrogated by deep sequencing (Sivakumar et al. 2017). Pathway-based enrichment analysis revealed increased activation of protumor immune pathways (Th2) as well as suppression of antitumor immune pathways (Th1) during the progression of normal lung to AAHs and further to LUADs. This was accompanied by inhibition of IFN- $\gamma$ and TGFB1 signaling, reduction in inflammatory responses, and increased expression of CCL2/CCR2, SPP1, and CD27 (Sivakumar et al. 2017). Another study by Lavin and colleagues (2017) showed, by paired single-cell sequencing of early-stage LUADs and non-involved tissue, that LUADs exhibit early impairment of adaptive immunity, lending support to the concept that, early on, lung tumors develop an immunosuppressive microenvironment (Lavin et al. 2017). Indeed, the notion that immunogenomic signatures of the lung are operative in early premalignant lesions and may thus dynamically modulate classical molecular aberrations is gaining momentum (Milette et al. 2019). Mascaux et al. (2019) outlined the location and timing of the successive and coevolutionary changes occurring in preinvasive LUSC lesions (CIS) as well as their microenvironment, 
up to invasive tumors. The authors report activation of resident immune cells was detected as early as in low-grade preinvasive regions, and they highlight immune pathways modulated across early and subsequent stages, such as negative regulation of the immune system, antigen processing, and the presentation of peptide antigens (Mascaux et al. 2019). They observed negative regulation of the immune system, antigen processing, and the presentation of peptide antigen in all stages of tumor development. The earliest immune events included the down-regulation of genes that negatively regulate the immune system, including TNFRSF14, CD200, CD59, TGFB3, and HLA-G. In contrast, in high-grade lesions and LUSC there was an upregulation of genes that promote immunosuppression (Mascaux et al. 2019). These findings are supported by another seminal report, which identified immune-based subtypes of bronchial premalignant lesions, highlighting a dynamic interplay between epithelial and immune pathways early on in premalignant lesions (Beane et al. 2019). Interestingly, down-regulation of genes involved in interferon signaling and T-cell-mediated immunity correlated with compromised adaptive and innate immunity and was a hallmark of progressive/persistent lesions compared to regressive lesions (Beane et al. 2019). Similarly, the early-stage lung tumors employ various ways of immune escape, including disruption of tumor antigen presentation by loss or reduction of HLA expression, mutation in antigen-presenting pathways (Chen et al. 1996), selection of mutations for low-affinity MHC binders (Wiedenfeld et al. 1994), or hypermethylation of the neoantigen promoters followed by silencing of neoantigen expression (Rosenthal et al. 2019). Taken together, these studies reveal that immune escape may occur before tumor invasion, lending support to the potential critical role of components of the premalignant immune microenvironment as determinants of lesion fate regulating progression or regression (Angelova et al. 2018). Consistent with these findings, a preexisting specific antitumor immune landscape is associated with response to immune checkpoint blockade therapy (Dhodapkar et al. 2013). Additional studies are warranted to further explore the existence of tu- mor microenvironment biomarkers in lung preneoplastic lesions (e.g., by characterizing immune infiltrates), as well as their potential clinical utility, such as tailoring adjuvant or neo-adjuvant immunotherapy strategies to restore specific aspects of the tumor immune microenvironment.

\section{PRECLINICAL HUMAN MODELS FOR THE STUDY OF LUNG CANCER PATHOGENESIS}

Various preclinical murine models of lung cancer, including those using (1) chemically induced lung tumorigenesis, (2) animals with the engineered genetic backgrounds that promote the development of spontaneous lung cancer, (3) xenograft or syngeneic tumor cells (Meuwissen and Berns 2005; de Seranno and Meuwissen 2010; Kwon and Berns 2013), and (4) models for studying immuno-oncology (Olson et al. 2018), have been developed. However, deciphering the pathogenesis of lung cancer was hindered by the lack of models allowing studying the earliest stages of lung cancer initiation and the mechanisms of progression from premalignancy to metastatic disease. This is in large part due to the lack of the cell lines that could be used to mimic the early events in transformation of the pulmonary epithelium. Early studies of lung cancer pathogenesis used normal human bronchial epithelium (NHBE) cells that were explanted from surgical resection specimens (Lechner et al. 1981). NHBE cells became senescent after up to 35 doublings and required feeder cells for their growth. Despite closely resembling the normal bronchial epithelium, NHBE cells had limited usability due to the complicated growth conditions and the relatively short life span. Thus, attempts have been made to establish immortalized bronchial epithelium cells. In one of the notable experiments, NHBE cells were rendered immortal by the transfer of SV40 virus early region genes (including small and large $\mathrm{T}$ antigens) with or without the Rous sarcoma virus long terminal repeat (Reddel et al. 1988). This method produced a series of cell lines with various life spans with a BEAS-2B cell line that was able to proliferate continuously being the most widely used in research. This cell line expressed SV40 T antigen and was prone to spontaneous transformation (Reddel et al. 1993). 
H. Kadara et al.

While BEAS-2B cells were more convenient to use than NHBE cells, they had significant limitations due to the presence of viral oncoproteins and could not represent a good lung premalignancy model. The significant advances in creating such a model in the absence of viral oncoprotein expression have been made by the development of human bronchial and small airway epithelium cell lines (HBEC and HSAEC, respectively). HBEC cells were immortalized by ectopic expression of cyclin-dependent kinase 4 (CDK4) and human telomerase reverse transcriptase (hTERT) (Ramirez et al. 2004), whereas HSAEC cells were immortalized by expressing hTERT, CDK4, and a dominant-negative form of p53 (Sasai et al. 2011) without the use of viral oncoproteins. Characterization of these cells demonstrated that they were immortal, but neither grew colonies in soft agar nor formed tumors in immunocompromised mice in vivo. Genomics and transcriptomics studies confirmed that HBEC and HSAEC cells were very close to their original parental small airway epithelium cells. Thus, immortalized HBEC and HSAEC cells constitute models of premalignancy in LUAD (HSAEC) or LUSC (HBEC). Development of HBEC and HSAEC cells has opened new avenues for studying early pathogenesis of lung cancer. A seminal study demonstrated that stepwise addition of oncogenic mutations to immortalized HBEC cells ( $\mathrm{p} 53$ knockdown [KD], introduction of oncogenic KRAS ${ }^{\mathrm{v} 12}$ and $\mathrm{EGFR}^{\mathrm{L} 858 \mathrm{R}}$ mutations) conferred the development of anchorageindependent growth (AIG) in soft agar and an invasive phenotype in a three-dimensional organotypic culture assay, but was not sufficient to transform the cells to cancer and enable tumor formation in immunocompromised mice (Sato et al. 2006). Subsequent studies have shown that manipulating the genetic background and gene expression in HBEC cells could drive epithelialto-mesenchymal transition (EMT) and a malignant transformation. One study reported that a combination of p53 KD, KRAS ${ }^{\mathrm{v} 12}$, and ectopic expression of CMYC was able to drive full malignant transformation of HBEC cells (Sato et al. 2013). In another study, ectopic expression of the transcriptional repressor Snail in p53 KD, KRAS $^{\mathrm{v} 12}$ HBEC cells enabled tumor formation,
EMT, and metastatic growth in a murine lung cancer model (Walser et al. 2018). Furthermore, this study demonstrated that, in the context of p53 KD, KRAS ${ }^{\mathrm{v} 12}$, HBEC Snail expression promoted the $\mathrm{ALDH}^{+} \mathrm{CD} 44^{+} \mathrm{CD} 24^{-}$stem cell population that in turn was required for AIG. Concordantly, ectopic expression of the transcriptional repressor Zeb1 induced malignant transformation of p53 KD, KRAS ${ }^{\mathrm{v} 2}$ HBEC cells (Larsen et al. 2016). These findings are consistent with previous reports indicating the multipotent capacity of HBEC cells consistent with basal cells (Delgado et al. 2011). Similarly, introduction of constitutively active PIK3CA ${ }^{\mathrm{H} 1047 \mathrm{R}}$, cyclin-D1, or dominant-negative $\mathrm{LKB1}^{\mathrm{D} 194 \mathrm{~A}}$ in combination with $\mathrm{KRAS}^{\mathrm{V} 12}$ induced malignant transformation and acquisition of LUAD phenotypes in HSAEC cells (Sasai et al. 2011). Moreover, exposure of HBEC cells to tobacco carcinogens induced stem-cell-like phenotypes and EMT via miR-205 and miR-200 epigenetic silencing (Tellez et al. 2011) and induced epigenetic silencing of the antiproliferative miRNA miR-196b thus increasing the proliferative capacity of the cells (Tellez et al. 2016). In a recent study, targeting of c-MYC-induced BCL6 by a small molecule drug was effective against transformed P53 KD, KRAS ${ }^{\mathrm{v} 12}$, $\mathrm{CMYC}^{+}$HBEC cells, thus demonstrating the utility of HBEC cells in facilitating the identification of actionable targets for oncogene-driven lung cancer (Deb et al. 2017). Another study used an isogenic pair of LUAD and immortalized HBEC cells to assess the tumor adaptive response to various targeted and chemotherapeutic agents ( $\mathrm{Zi}$ et al. 2020). To summarize, HBEC and HSAEC cells constitute a unique model of pulmonary premalignancy that allow evaluation of the role of different driver genes (or gene combinations) in malignant transformation both in vitro and in vivo as well as facilitating identification of actionable targets for lung cancer treatment and prevention.

\section{BIOLOGICAL RATIONALE FOR EARLY DIAGNOSIS AND LUNG CANCER SCREENING}

The goal of cancer screening is to increase the likelihood of cure by detecting the malignancy, 
Early Diagnosis and Screening for Lung Cancer

or its precursor lesion, at an early stage prior to the onset of symptoms, when treatment is most effective. Wilson and Jungner published several key principles that should be considered when evaluating the role of screening for a particular disease that provides a framework for considering the role of screening for lung cancer (Wilson and Jungner 1968). These principles include knowledge of its natural progression and the performance characteristics of available screening tests and availability of effective treatment strategies for early-stage disease.

One key principle outlined by Wilson and Junger is the need for a recognizable latent or preclinical stage of disease. At present, the most successful cancer screening approaches have been implemented in cervical and colon cancer, where studies have demonstrated a clear period of asymptomatic preclinical disease. In concert, the evidence regarding carcinogenesis in these malignancies suggests a stepwise progression to more invasive and advanced stages of cancer. In these two cancers, screening allows for the identification of precursor lesions (e.g., cervical intraepithelial neoplasia with cervical cancer screening and colonic polyps with colorectal cancer screening) allowing for early diagnosis and treatment.

Lung carcinogenesis is a complex, stepwise process that involves the acquisition of genetic mutations and epigenetic changes that alter cellular processes, such as proliferation, differentiation, invasion, immune responsiveness, and metastasis. Findings from molecular studies support a stepwise lung carcinogenesis model in which development of a field of cancerization-the accumulation of molecular abnormalities from repeated injury (e.g., cigarette smoke) -leads to genetically and epigenetically altered cells that play a central role (Gomperts et al. 2011). Early lung cancer lesions are polyclonal and driver mutations present in late-stage disease, with tumor development occurring via large-scale genomic rearrangements and copy number changes (Beane et al. 2017). Although the process is clearly complex, several important principles are apparent. In particular, there is increasing evidence that lung cancers are not uniform in their biology and that not all early lesions (such as AAH and AIS) lead to invasive cancer (Tanoue et al. 2015; Vachani et al. 2017).

\section{CURRENT STATUS OF LUNG CANCER SCREENING INCLUDING RESULTS AND OBSTACLES}

In the 1970s, the main efforts to develop screening tests for lung cancer were based on chest radiography and sputum cytology (Vachani et al. 2017). Randomized controlled trials assessing these modalities failed to show a reduction in lung cancer mortality. Because of concerns regarding limited power and contamination of the control arms, screening with chest radiography was further evaluated as a part of the Prostate, Lung, Colorectal, and Ovarian (PLCO) trial, which randomized more than 154,000 patients, including both smokers and nonsmokers, to annual radiography or usual care. Annual chest radiographic screening for up to 4 years did not have an effect on lung cancer mortality with 13 years of follow-up in the trial (Oken et al. 2011).

In the 1990s, interest in lung cancer screening turned to use of low-dose computed tomography (LDCT), which provided a more sensitive method for the detection of pulmonary nodules than chest radiography. Multiple single-arm studies went on to demonstrate two key findings: although LDCT identified a large number of noncalcified lung nodules, most of which were not malignant, it resulted in a higher proportion of early-stage lung cancers compared with historical data (Bach et al. 2003). Given these promising results, the National Cancer Institute launched the National Lung Screening Trial (NLST) in 2002, randomizing 53,454 patients at high risk (defined as age 55-74 years; tobacco pack-years 30; and, if a previous smoker, quit within 15 years) to either annual LDCT or chest radiography for 3 years (National Lung Screening Trial Research Team et al. 2011a). After 7 years of follow-up, the LDCT arm demonstrated a reduction in lung cancer-specific mortality from $1.66 \%$ to $1.33 \%$ (a $20 \%$ relative reduction) (National Lung Screening Trial Research Team et al. 2011b), as well as a reduction in all-cause mortality. 
H. Kadara et al.

Although the NLST represents a landmark advance in lung cancer screening, implementation of screening programs has been slow, in part due to concerns regarding the high falsepositive rate and potential for harm to individuals without lung cancer. Among all LDCT scans, $24 \%$ were classified as positive (i.e., identified at least one nodule $4 \mathrm{~mm}$ in size), with $96 \%$ ultimately proven to be falsely positive. Although the subsequent evaluation after a positive finding was most commonly surveillance imaging, and the use of invasive procedures was relatively infrequent, $4 \%$ of LDCT participants underwent surgical lung biopsy after the baseline scan, identifying benign disease in 29\% of these procedures (Tanoue et al. 2015).

In addition to NLST, a Dutch-Belgian lung cancer screening trial (Nederlands-Leuvens Longkanker Screenings Onderzoek [NELSON]) that randomized 15,822 high-risk participants to LDCT screening versus no screening, has recently been completed (de Koning et al. 2020). The NELSON trial design has several important differences when compared to the NLST, including the lack of chest X-ray in the control arm, the use of volumetric imaging for lung nodule assessment, and the inclusion of more rounds of screening. The results of this trial indicate an even more robust reduction in lung cancer-specific mortality with LDCT than what was observed in NLST (de Koning et al. 2020).

The use of current patient selection criteria for screening, based on the NLST and NELSON, results in the need to screen a large segment of the population, due to the dearth of approaches for individualized risk assessment. Use of LDCT within the vast "high-risk" population creates a higher likelihood of false-positive detection resulting in frequent diagnostic and management dilemmas for physicians, while patients face confusion, anxiety, and harm from unnecessary procedures. Recent efforts have focused on improving the ability to identify individuals who are more likely to benefit from LDCT screening. Studies have shown that the use of age and smoking history alone is less efficient than "personalized" approaches employing more complex risk models that consider other variables (e.g., COPD, family history, race), which improves the predic- tion of future lung cancer development (Tammemägi et al. 2013, 2017; Katki et al. 2016, 2018). Although approaches to develop personalized or "precision" screening may allow for the identification of patients at higher risk of lung cancer, they may also result in screening of patients that are at risk of death from competing causes, resulting in less benefit from lung cancer screening (Rivera et al. 2018). One potential approach to improve patient identification includes the incorporation of molecular biomarkers that may identify patients at the highest risk of future disease (Seijo et al. 2019). To this end, a number of different biomarkers are in various stages of development and validation for use in risk prediction models.

Screening with LDCT with currently accepted patient selection criteria has several other important shortcomings. The significant molecular heterogeneity among lung cancers results in a failure to detect clinically relevant cancer early enough to intervene. Conversely, screening also results in the identification of some proportion of clinically insignificant cancers; these indolent lesions, frequently manifesting as smaller ground glass pulmonary nodules that represent $\mathrm{AAH}$ or AIS lesions, may never progress to invasive cancers but can still result in the need for additional imaging and invasive procedures. Finally, limiting screening to individuals meeting selection criteria employed in the NLST and NELSON results in the inability to identify cancers early in those who fall outside of these criteria. Evidence from the United States suggests that at least half of all new lung cancers occur in patients not currently meeting these criteria, which serve as the basis for patient selection in various current guidelines (Wang et al. 2015). The development of molecular biomarkers that identify higher risk individuals may facilitate approaches that allow for LDCT screening of a broader population resulting in a greater reduction in lung cancer mortality at the population level.

In spite of these limitations, LDCT screening represents a proven path for reduction in lung cancer mortality in the high-risk smoking subset of patients. Even though only a subset of lung cancers arise in the screen-eligible population, they are clearly at higher risk and only a 
small subset of these patients eligible to be screened currently do so. Additional efforts on education are needed (Pham et al. 2018).

\section{SPUTUM AND BLOOD MARKERS FOR LUNG CANCER RISK ASSESSMENT (DNA METHYLATION, PROTEOMICS, CELL-FREE DNA)}

Risk assessment is fundamental to increase opportunities for curative treatments in lung cancer patients. Recently, there has been much effort expended to develop sputum and blood markers for lung cancer assessment. Aberration of DNA methylation is an important characteristic of tumor tissue. Its prevalence and early occurrence in tumor have stimulated the development of lung cancer screening approaches using methylation of cell-free DNA (cfDNA). Leng et al. (2017) employed an eight-gene methylation panel to build a classifier in sputum for lung cancer risk among CT-screen eligible smokers (Leng et al. 2017). The cfDNA methylation panel achieved an accuracy of $82 \%-86 \%$ for lung cancer prediction. Combined with clinical variables, the accuracy has been further improved to $87 \%-90 \%$. Comparing the prediction based only on clinical variables to its inclusion with methylation, the specificity increased from $25 \%$ to $54 \%$ at a sensitivity of $95 \%$. Hulbert et al. (2017) described a three-gene model discriminating individuals with suspicious nodules on CT imaging with 98\% sensitivity and 71\% specificity using sputum samples $(N=210)$ from stage I or II NSCLC patients and controls (Hulbert et al. 2017). Blood cfDNA methylation is also widely used for lung cancer risk assessment. In addition to sputum samples, Hulbert et al. (2017) reached a 93\% sensitivity and 62\% specificity using plasma samples. Genome-wide methylation profiling is perhaps the most powerful tool to explore methylome and has been used in early detection of lung cancer. Kang et al. (2017) has proposed a model that simultaneously infers the proportion and tissue of origin based on cfDNA methylation (Kang et al. 2017). Their methods showed promising results in classification of plasma samples from liver and lung cancer patients. Another method based on haplotype blocks of cfDNA methylation was developed by Guo et al. (2017) for the detection of various kinds of cancer, including lung cancer (Guo et al. 2017). Shen et al. (2018) developed an immunoprecipitation-based protocol to profile cfDNA methylome, and showed a high AUC of 0.975 on 32 stage I-II lung cancer patients.

Apart from cfDNA methylation, proteins are promising markers for lung cancer diagnosis. Integrative Analysis of Lung Cancer Etiology and Risk (INTEGRAL) Consortium for Early Detection of Lung Cancer developed a biomarker risk score based on four circulating proteins (CA125, CEA, CYFRA 21-1, and Pro-SFTPB). An integrated risk prediction model that combined smoking exposure with the biomarker risk score yielded an AUC of 0.83 in the validation study of 63 ever-smoking patients with lung cancer and 90 matched controls (INTEGRAL Consortium for Early Detection of Lung Cancer et al. 2018). The CancerSEEK test combined both somatic mutations and a panel of protein markers to detect and locate cancer. It showed a sensitivity of $\sim 60 \%$ on 104 stage I-III lung cancer patients (Cohen et al. 2018). Several studies explored the presence and expression of tumor-related proteins in sputum. Sun et al. (2009) found a significant elevation in expression of a proliferation-inducing ligand in sputum of lung cancer patients compared with controls ( $82 \%$ vs. 3\%) (Sun et al. 2009). Pio et al. (2010) showed increased levels of complement factor $\mathrm{H}$ in sputum of lung cancer patients (Pio et al. 2010).

\section{EARLY DETECTION OF RELAPSE/ RECURRENCE}

\section{Circulating Tumor Cells}

Liquid biopsy analyzing circulating tumor cells (CTCs) has been explored as an approach for early detection of relapse and recurrence in lung cancer (Gallo et al. 2017; Blackhall et al. 2018; Kapeleris et al. 2018). CTCs represent disseminated tumor cells from the primary site into the circulation with the potential to metastasize at distant organs. CTCs can be obtained noninvasively at multiple time points, which potentially could provide a real-time assessment of 
H. Kadara et al.

patients' disease progression and clinical response to therapy. The detection of CTCs could precede the onset of clinical or radiological signs of metastasis or local recurrence, thus providing an opportunity to stratify patients for the most effective treatment option at a much earlier course in the disease. Regional tumor biopsy may not reflect intratumoral heterogeneity of lung cancer as well as heterogeneity at the sites of micrometastases. Therefore, it has been hypothesized that assessing CTCs could overcome this problem by revealing clonal diversity as tumor cells in the blood are originating from primary as well as metastatic tumor sites.

\section{Isolation of CTCS}

CTCs can be enriched and isolated from whole blood by cell surface marker-dependent or -independent approaches (Pantel and Alix-Panabieres 2019). The marker-dependent approach exploits the differential expression of surface proteins between tumor cells and blood cells, either by positive or negative selection. For example, the epithelial cell adhesion molecule (EpCAM) is the most frequently used marker for positive selection, which is the basis for the FDA-approved CellSearch system (Riethdorf et al. 2007). Of note, CTCs are phenotypically heterogeneous and may not express a chosen marker. In addition, CTCs from NSCLC often exhibit EMT characteristics and thus are EpCAM-negative. Using multiple surface markers to capture CTCs could alleviate these problems. Winer-Jones et al. (2014) used a mixture of antibodies to EpCAM, Her2, MelCAM, Muc1, and Trop2 to efficiently recover tumor cells from blood. Furthermore, the use of negative selection whereby nonmalignant cells are depleted by staining with lineage-specific markers, such as CD45 for leukocytes, CD146, or CD31 for endothelial cells, and CD34 for hematopoietic stem cells, may be used to capture the subsets of CTCs that do not express the established CTC surface markers (He et al. 2008). Alternatively, CTCs can be isolated in a markerindependent fashion based on their physical properties. This can include size (the isolation by size of epithelial tumor cells [ISET]) (Vona et al. 2000), density (Weitz et al. 1998), electric charge (Abonnenc et al. 2013; Peeters et al. 2013), and deformability (Aghaamoo et al. 2015). A study that compared ISET and CellSearch approaches demonstrated that ISET had higher sensitivity in detecting CTCs, consistent with the concept that CTCs in NSCLC may undergo EMT and lose the EpCAM expression (Krebs et al. 2012).

\section{Characterization of CTCs}

Purified CTCs can be characterized at DNA, RNA, and protein levels by various approaches (Pantel and Alix-Panabieres 2019; Kolinsky et al. 2020). Chromosomal aberrations, copy number variation, and mutations in CTCs can be identified by fluorescence in situ hybridization (FISH) and targeted by whole exome sequencing (WES); sequencing usually requires prior whole-genome amplification (Lin et al. 2017; Pailler et al. 2017; Faugeroux et al. 2020). Expression of individual genes and the transcriptome of CTCs can be assessed by quantitative RT-PCR (Markou et al. 2018) or RNA sequencing at bulk or single-cell levels. Multiplex immunophenotyping and proteomics can provide insights at the protein level (Matthew et al. 2016; Rugo et al. 2018). In addition, functional assays such as Epithelial ImmunoSPOT (EPISPOT) and EPISPOT in a drop (EPIDROP) are being developed to detect specific proteins secreted or released by CTCs as a readout for viable CTCs in short-term culture (Kuske et al. 2016; Eyer et al. 2017). Last, recent advances in the culture of CTCs and in vivo xenotransplantation of CTCs have made it feasible to perform functional and mechanistic studies of CTCs in mediating metastasis and response or resistance to treatments (Hodgkinson et al. 2014; Zhang et al. 2014b; Hamilton et al. 2015; Drapkin et al. 2018).

\section{CTCs in Early-Stage NSCLC}

As a result of improvements in the sensitivity of detecting CTCs, it has been revealed that CTCs can be used as prognostic and predictive markers in NSCLC (Gallo et al. 2017). Studies have addressed the prognostic value of CTCs in earlystage NSCLC. Different mRNA markers, in- 
cluding carcinoembryonic antigen (CEA), survivin, thyroid transcription factor-1 (TTF-1), and lung-specific $\mathrm{X}$ protein (LUNX), have been assessed in CTCs in pre- and postoperative peripheral blood samples from stage I-III NSCLC patients. CTCs expressing these mRNAs were identified as independent prognostic markers associated with reduced overall survival (OS) and shorter disease-free survival (DFS) (Yamashita et al. 2002; Yie et al. 2009; Yoon et al. 2011; Li et al. 2014). Using ISET technology, CTCs were found in presurgery peripheral blood samples in $49 \%$ of NSCLC patients undergoing curative surgery, and a CTC count of $\geq 50$ was significantly associated with shorter OS and DFS (Hofman et al. 2011). In addition, CTCs were identified by immunocytochemical methods in tumor-draining pulmonary vein or peripheral blood samples of NSCLC patients postsurgery, which was associated with a shorter DFS (Sienel et al. 2003). A recent clinical trial monitoring CTCs in stage I NSCLC treated with stereotactic body radiation therapy (SBRT) revealed that positive CTC counts following therapy and predating clinical progression are associated with disease recurrence, while negative CTCs correlated with disease control (Frick et al. 2018). A meta-analysis of five studies in which early-stage NSCLC patients underwent surgical resection, demonstrated that positive CTCs postsurgery indicate a poor prognosis for DFS (Liang et al. 2018). A recent study using single-cell transcriptome of CTCs revealed a refined signature of gene expression as a predictive biomarker of metastatic risk in early-stage NSCLC with high risk of recurrence (Lim et al. 2019).

\section{CTCs in Advanced NSCLC}

The role of CTC as a prognostic biomarker in advanced NSCLC patients has been demonstrated by multiple studies (Gallo et al. 2017). Using the CellSearch system in chemo-naive advanced disease or metastatic NSCLC patients who received first-line chemotherapy, it was shown that a baseline count of CTC $\geq 5$ was significantly associated with a shorter progression-free survival (PFS) and OS (Krebs et al. 2011; Muinelo-
Romay et al. 2014). A reduction in CTC postchemotherapy was predictive of longer PFS and OS. Additional studies using alternative approaches for CTC isolation, such as gradient centrifugation or using survivin mRNA as a surrogate marker of CTCs, revealed the correlation between low-baseline CTCs and improved PFS and OS (Du et al. 2014; Zhang et al. 2016). Consistently, detection of CTCs by multiple markers increased the sensitivity and confirmed that high CTC load correlated with a shortened OS in advanced NSCLC patients receiving chemotherapy (Sher et al. 2005; Liu et al. 2008). Similarly, a recent study using an adenoviral probe that detects elevated telomerase activity to track CTCs in patients with locally advanced NSCLC receiving chemoradiation therapy revealed that increased CTCs post-therapy correlated with disease recurrence, which preceded radiographic evidence of recurrence (Chinniah et al. 2019). CTC count has been evaluated in targeted therapy of EGFR tyrosine kinase inhibitors (TKIs) in NSCLC. A high baseline CTC count by a CellSearch test correlated with response to EGFR TKI treatment, whereas a decrease in CTC following treatment predicted a longer PFS (Punnoose et al. 2012). In a separate study using flow cytometry to detect CTC in EGFR-mutant advanced NSCLC, patients with low CTCs had a superior EGFR TKI response rate, PFS, and OS (He et al. 2016). PD-L1 expression on CTCs has been recently evaluated as a potential biomarker to predict response and relapse for NSCLC patients undergoing immune checkpoint inhibitor (ICI) immunotherapy (Hofman et al. 2019). Studies suggested that PD-L1 expression on CTCs could serve as a surrogate for tracking changes following ICI treatment (Adams et al. 2017; Ilié et al. 2018). Pretreatment $\mathrm{PD}-\mathrm{L1}^{+}$CTCs were found to be associated with poor prognosis in patients treated with PD-1 inhibitors (Guibert et al. 2018; Kallergi et al. 2018), and persistence of PD-L1 ${ }^{+}$CTCs post-ICI treatment might mirror resistance to therapy (Nicolazzo et al. 2016).

\section{CTCs in SCLC}

The prognostic value of CTCs has also been assessed in small-cell lung cancer (SCLC). SCLC is 
H. Kadara et al.

a highly aggressive neuroendocrine cancer with early metastatic potential and poor outcomes (Gazdar et al. 2017). CTC counts are considerably higher in patients with SCLC than those with NSCLC, indicating a pronounced disseminative activity of SCLC (Blackhall et al. 2018). CTC analyses in SCLC patients revealed that CTC numbers fell rapidly after one cycle of chemotherapy, and that CTC counts $\geq 50$ before or persisting post-chemotherapy is associated with reduced OS (Hou et al. 2009, 2012). Several other studies have independently confirmed that baseline CTC counts correlate with OS, although no consensus has been reached for an optimal cutoff threshold (Hiltermann et al. 2012; Naito et al. 2012; Zhang et al. 2014a; Cheng et al. 2016). Changes in CTC counts during treatment provide further prognostic information (Normanno et al. 2014).

\section{Cell-Free DNA}

Following surgery, many lung cancer patients may have minimal residual disease (MRD), which can result in recurrence. The early detection of recurrence could offer new therapeutic approaches for improving outcomes following surgery (Luskin et al. 2018). In a landmark study, next-generation sequencing (NGS)-based and patient-specific mutational panel assays comprising 12-30 single-nucleotide variants (SNVs), detected from phylogenetic tumor cfDNA profiling, were developed and used in 25 patients enrolled in the TRACERx lung cancer study (Abbosh et al. 2017). The detection of SNVs in tumor cfDNA showed correlation with clinical evidence of NSCLC recurrence. The threshold of tumor cfDNA detection was $<0.1 \%$, and the median lead time to clinical and radiological detection of relapse was 70 days (10-346 days) (Abbosh et al. 2018). Another study showed that a panel of 128 genes targeted by CAPP-Seq can detect tumor cfDNA in the first posttreatment blood sample, in which tumor cfDNA was detected before radiological recurrence with an average lead time of 5.2 months in $72 \%$ of patients (Chaudhuri et al. 2017). This study concluded that tumor cfDNA analysis can predict relapse prior to clinically evident recurrence.
In addition to detecting tumor-specific DNA mutations, gene methylation in liquid biopsies has been used to evaluate risk of recurrence in lung cancer. Belinsky et al. (2017) showed the potential use of an eight-gene methylation panel in plasma and sputum to predict lung cancer recurrence following resection for stage I NSCLC. These results demonstrated that patients with one or more methylated genes in the plasma had an increased risk of recurrence with a significant hazard ratio of 1.5 .

Longitudinal cfDNA analyses can provide not only opportunity for posttreatment monitoring but also insights into tumor evolution (Abbosh et al. 2017). Subclonal structures, which seed relapse, can be identified by mapping SNVs detected in posttreatment plasma back to pretreatment data. This may facilitate treatments that target the evolving tumor subclones.

\section{CONCLUSIONS}

Understanding of the molecular basis for lung cancer pathogenesis and technologies for molecular early detection are improving rapidly, as are technologies for monitoring of disease burden and noninvasive assessment of prognosis and prediction of treatment response. Clinical application of LDCT screening is coming into clinical practice, but an improved understanding of molecular risk factors and noninvasive diagnostic assays to assist in management of indeterminate pulmonary nodules is needed.

\section{ACKNOWLEDGMENTS}

K.K.'s work on this topic was supported by the Department of Defense (DOD) W81XWH-161-0194 and University of California TobaccoRelated Disease Research Program (TRDRP) 27IR-0036 Grants. The work of X.J.Z. and S.L. was supported by the National Institutes of Health (NIH) Grants U01CA230705, R01CA246329, and U01CA237711. 


\section{REFERENCES}

Abbosh C, Birkbak NJ, Wilson GA, Jamal-Hanjani M, Constantin T, Salari R, Le Quesne J, Moore DA, Veeriah S, Rosenthal R, et al. 2017. Phylogenetic ctDNA analysis depicts early-stage lung cancer evolution. Nature 545: 446-451. doi:10.1038/nature22364

Abbosh C, Birkbak NJ, Swanton C. 2018. Early stage NSCLC -challenges to implementing ctDNA-based screening and MRD detection. Nat Rev Clin Oncol 15: 577-586. doi:10.1038/s41571-018-0058-3

Abonnenc M, Manaresi N, Borgatti M, Medoro G, Fabbri E, Romani A, Altomare L, Tartagni M, Rizzo R, Baricordi O, et al. 2013. Programmable interactions of functionalized single bioparticles in a dielectrophoresis-based microarray chip. Anal Chem 85: 8219-8224. doi:10.1021/ ac401296m

Adams DL, Adams DK, He J, Kalhor N, Zhang M, Xu T, Gao H, Reuben JM, Qiao Y, Komaki R, et al. 2017. Sequential tracking of PD-L1 expression and RAD50 induction in circulating tumor and stromal cells of lung cancer patients undergoing radiotherapy. Clin Cancer Res 23: 5948-5958. doi:10.1158/1078-0432.CCR-17-0802

Aghaamoo M, Zhang Z, Chen X, Xu J. 2015. Deformabilitybased circulating tumor cell separation with conicalshaped microfilters: concept, optimization, and design criteria. Biomicrofluidics 9: 034106. doi:10.1063/1.492 2081

Angelova M, Mlecnik B, Vasaturo A, Bindea G, Fredriksen T, Lafontaine L, Buttard B, Morgand E, Bruni D, JouretMourin A, et al. 2018. Evolution of metastases in space and time under immune selection. Cell 175: 751-765.e16. doi:10.1016/j.cell.2018.09.018

Anichini A, Tassi E, Grazia G, Mortarini R. 2018. The nonsmall cell lung cancer immune landscape: emerging complexity, prognostic relevance and prospective significance in the context of immunotherapy. Cancer Immunol Immunother 67: 1011-1022. doi:10.1007/s00262-0182147-7

Bach PB, Kelley MJ, Tate RC, McCrory DC. 2003. Screening for lung cancer: a review of the current literature. Chest 123: 72S-82S. doi:10.1378/chest.123.1_suppl.72S

Balsara BR, Pei J, Mitsuuchi Y, Page R, Klein-Szanto A, Wang H, Unger M, Testa JR. 2004. Frequent activation of AKT in non-small cell lung carcinomas and preneoplastic bronchial lesions. Carcinogenesis 25: 2053-2059. doi:10.1093/carcin/bgh226

Bass AJ, Watanabe H, Mermel CH, Yu S, Perner S, Verhaak RG, Kim SY, Wardwell L, Tamayo P, Gat-Viks I, et al 2009. SOX2 is an amplified lineage-survival oncogene in lung and esophageal squamous cell carcinomas. Nat Genet 41: 1238-1242. doi:10.1038/ng.465

Bayarri-Lara C, Ortega FG, Cueto Ladrón de Guevara A, Puche JL, Ruiz Zafra J, de Miguel-Pérez D, Sánchez-Palencia Ramos A, Giraldo-Ospina CF, Navajas Gómez JA Delgado-Rodriguez M, et al. 2016. Circulating tumor cells identify early recurrence in patients with non-small cell lung cancer undergoing radical resection. PLOS ONE 11: e0148659. doi:10.1371/journal.pone.0148659

Beane J, Campbell JD, Lel J, Vick J, Spira A. 2017. Genomic approaches to accelerate cancer interception. Lancet On col 18: e494-e502. doi:10.1016/S1470-2045(17)30373-X
Beane JE, Mazzilli SA, Campbell JD, Duclos G, Krysan K, Moy C, Perdomo C, Schaffer M, Liu G, Zhang S, et al. 2019. Molecular subtyping reveals immune alterations associated with progression of bronchial premalignant lesions. Nat Commun 10: 1856. doi:10.1038/s41467019-09834-2

Belinsky SA, Palmisano WA, Gilliland FD, Crooks LA, Divine KK, Winters SA, Grimes MJ, Harms HJ, Tellez CS Smith TM, et al. 2002. Aberrant promoter methylation in bronchial epithelium and sputum from current and former smokers. Cancer Res 62: 2370-2377.

Belinsky SA, Leng S, Wu G, Thomas CL, Picchi MA, Lee SJ, Aisner S, Ramalingam S, Khuri FR, Karp DD. 2017. Gene methylation biomarkers in sputum and plasma as predictors for lung cancer recurrence. Cancer Prev Res (Phila) 10: $635-640$

Blackburn EH. 2011. Cancer interception. Cancer Prev Res (Phila) 4: 787-792.

Blackhall F, Frese KK, Simpson K, Kilgour E, Brady G, Dive C. 2018. Will liquid biopsies improve outcomes for patients with small-cell lung cancer? Lancet Oncol 19: e470e481. doi:10.1016/S1470-2045(18)30455-8

Bonner AE, Lemon WJ, Devereux TR, Lubet RA, You M. 2004. Molecular profiling of mouse lung tumors: association with tumor progression, lung development, and human lung adenocarcinomas. Oncogene 23: 1166 1176. doi:10.1038/sj.onc. 1207234

Chaudhuri AA, Chabon JJ, Lovejoy AF, Newman AM, Stehr H, Azad TD, Khodadoust MS, Esfahani MS, Liu CL, Zhou L, et al. 2017. Early detection of molecular residual disease in localized lung cancer by circulating tumor DNA profiling. Cancer Discov 7: 1394-1403. doi:10.1158/21598290.CD-17-0716

Chen HL, Gabrilovich D, Tampé R, Girgis KR, Nadaf S, Carbone DP. 1996. A functionally defective allele of TAP1 results in loss of MHC class I antigen presentation in a human lung cancer. Nat Genet 13: 210-213. doi:10 .1038/ng0696-210

Chen H, Carrot-Zhang J, Zhao Y, Hu H, Freeman SS, Yu S, Ha G, Taylor AM, Berger AC, Westlake L, et al. 2019. Genomic and immune profiling of pre-invasive lung adenocarcinoma. Nat Commun 10: 5472. doi:10.1038/ s41467-019-13460-3

Cheng Y, Liu XQ, Fan Y, Liu YP, Liu Y, Liu Y, Ma LX, Liu XH, Li H, Bao HZ, et al. 2016. Circulating tumor cell counts/ change for outcome prediction in patients with extensivestage small-cell lung cancer. Future Oncol 12: 789-799. doi: $10.2217 /$ fon. 15.346

Chinniah C, Aguarin L, Cheng P, Decesaris C, Cutillo A, Berman AT, Frick M, Doucette A, Cengel KA, Levin W, et al. 2019. Early detection of recurrence in patients with locally advanced non-small-cell lung cancer via circulating tumor cell analysis. Clin Lung Cancer 20: 384-390.e2. doi:10.1016/j.cllc.2019.04.011

Chmara M, Wozniak A, Ochman K, Kobierska G, Dziadziuszko R, Sosinska-Mielcarek K, Jassem E, Skokowski J Jassem J, Limon J. 2004. Loss of heterozygosity at chromosomes $3 \mathrm{p}$ and $17 \mathrm{p}$ in primary non-small cell lung cancer. Anticancer Res 24: 4259-4263.

Cohen JD, Li L, Wang Y, Thoburn C, Afsari B, Danilova L, Douville C, Javed AA, Wong F, Mattox A, et al. 2018. Detection and localization of surgically resectable cancers 
H. Kadara et al.

with a multi-analyte blood test. Science 359: 926-930. doi:10.1126/science.aar3247

Deb D, Rajaram S, Larsen JE, Dospoy PD, Marullo R, Li LS, Avila K, Xue F, Cerchietti L, Minna JD, et al. 2017. Combination therapy targeting BCL6 and phospho-STAT3 defeats intratumor heterogeneity in a subset of non-small cell lung cancers. Cancer Res 77: 3070-3081. doi:10.1158/ 0008-5472.CAN-15-3052

de Bruin EC, McGranahan N, Mitter R, Salm M, Wedge DC, Yates L, Jamal-Hanjani M, Shafi S, Murugaesu N, Rowan AJ, et al. 2014. Spatial and temporal diversity in genomic instability processes defines lung cancer evolution. Science 346: 251-256. doi:10.1126/science. 1253462

de Koning HJ, van der Aalst CM, de Jong PA, Scholten ET, Nackaerts K, Heuvelmans MA, Lammers JW, Weenink C, Yousaf-Khan U, Horeweg N, et al. 2020. Reduced lungcancer mortality with volume $\mathrm{CT}$ screening in a randomized trial. N Engl J Med 382: 503-513. doi:10.1056/NEJ Moa1911793

Delgado O, Kaisani AA, Spinola M, Xie XJ, Batten KG, Minna JD, Wright WE, Shay JS. 2011. Multipotent capacity of immortalized human bronchial epithelial cells. PLoS ONE 6: e22023. doi:10.1371/journal.pone.0022023

de Seranno S, Meuwissen R. 2010. Progress and applications of mouse models for human lung cancer. Eur Respir J 35: 426-443. doi:10.1183/09031936.00124709

Dhodapkar KM, Gettinger SN, Das R, Zebroski H, Dhodapkar MV. 2013. SOX2-specific adaptive immunity and response to immunotherapy in non-small cell lung cancer. Oncoimmunology 2: e25205. doi:10.4161/onci.25205

Drapkin BJ, George J, Christensen CL, Mino-Kenudson M, Dries R, Sundaresan T, Phat S, Myers DT, Zhong J, Igo P, et al. 2018. Genomic and functional fidelity of small cell lung cancer patient-derived xenografts. Cancer Discov 8: 600-615. doi:10.1158/2159-8290.CD-17-0935

Du YJ, Li J, Zhu WF, Wu Y, Tang XP, Wang Y, Hu YM. 2014 Survivin mRNA-circulating tumor cells predict treatment efficacy of chemotherapy and survival for advanced nonsmall cell lung cancer patients. Tumour Biol 35: 44994507. doi:10.1007/s13277-013-1592-3

Eyer K, Doineau RCL, Castrillon CE, Briseño-Roa L, Menrath V, Mottet G, England P, Godina A, Brient-Litzler E Nizak C, et al. 2017. Single-cell deep phenotyping of IgGsecreting cells for high-resolution immune monitoring. Nat Biotechnol 35: 977-982. doi:10.1038/nbt.3964

Faugeroux V, Lefebvre C, Pailler E, Pierron V, Marcaillou C, Tourlet S, Billiot F, Dogan S, Oulhen M, Vielh P, et al. 2020. An accessible and unique insight into metastasis mutational content through whole-exome sequencing of circulating tumor cells in metastatic prostate cancer. Eur Urol Oncol 3: 498-508. doi:10.1016/j.euo.2018.12.005

Frick MA, Kao GD, Aguarin L, Chinniah C, SwisherMcClure S, Berman AT, Levin WP, Cengel KA, DeCesaris C, Hahn SM, et al. 2018. Circulating tumor cell assessment in presumed early stage non-small cell lung cancer patients treated with stereotactic body radiation therapy: a prospective pilot study. Int J Radiat Oncol Biol Phys 102: 536-542. doi:10.1016/j.ijrobp.2018.06.041

Gallo M, De Luca A, Maiello MR, D'Alessio A, Esposito C, Chicchinelli N, Forgione L, Piccirillo MC, Rocco G, Morabito A, et al. 2017. Clinical utility of circulating tumor cells in patients with non-small-cell lung cancer.
Transl Lung Cancer Res 6: 486-498. doi:10.21037/tlcr 2017.05.07

Gazdar AF, Bunn PA, Minna JD. 2017. Small-cell lung cancer: what we know, what we need to know and the path forward. Nat Rev Cancer 17: 725-737. doi:10.1038/nrc .2017 .87

Ghaffar H, Sahin F, Sanchez-Cepedes M, Su GH, Zahurak M, Sidransky D, Westra WH. 2003. LKB1 protein expression in the evolution of glandular neoplasia of the lung. Clin Cancer Res 9: 2998-3003.

Gomperts BN, Spira A, Massion PP, Walser TC, Wistuba II, Minna JD, Dubinett SM. 2011. Evolving concepts in lung carcinogenesis. Semin Respir Crit Care Med 32: 32-43. doi:10.1055/s-0031-1272867

Guibert N, Delaunay M, Lusque A, Boubekeur N, Rouquette I, Clermont E, Mourlanette J, Gouin S, Dormoy I, Favre $\mathrm{G}$, et al. 2018. PD-L1 expression in circulating tumor cells of advanced non-small cell lung cancer patients treated with nivolumab. Lung Cancer 120: 108-112. doi:10.1016/ j.lungcan.2018.04.001

Guo S, Diep D, Plongthongkum N, Fung HL, Zhang K. 2017. Identification of methylation haplotype blocks aids in deconvolution of heterogeneous tissue samples and tumor tissue-of-origin mapping from plasma DNA. Nat Genet 49: 635-642. doi:10.1038/ng.3805

Hamilton G, Burghuber O, Zeillinger R. 2015. Circulating tumor cells in small cell lung cancer: ex vivo expansion. Lung 193: 451-452. doi:10.1007/s00408-015-9725-7

He W, Kularatne SA, Kalli KR, Prendergast FG, Amato RJ, Klee GG, Hartmann LC, Low PS. 2008. Quantitation of circulating tumor cells in blood samples from ovarian and prostate cancer patients using tumor-specific fluorescent ligands. Int J Cancer 123: 1968-1973. doi:10.1002/ijc .23717

He W, Li W, Jiang B, Chang L, Jin C, Tu C, LI Y. 2016. Correlation between epidermal growth factor receptor tyrosine kinase inhibitor efficacy and circulating tumor cell levels in patients with advanced non-small cell lung cancer. Onco Targets Ther 9: 7515-7520. doi:10.2147/ OTT.S115221

Hiltermann TJ, Pore MM, van den Berg A, Timens W, Boezen HM, Liesker JJ, Schouwink JH, Wijnands WJA, Kerner GSMA, Kruyt FAE, et al. 2012. Circulating tumor cells in small-cell lung cancer: a predictive and prognostic factor. Ann Oncol 23: 2937-2942. doi:10.1093/annonc/ mds 138

Hirsch FR, Prindiville SA, Miller YE, Franklin WA, Dempsey EC, Murphy JR, Bujnn PA Jr, Kennedy TC. 2001. Fluorescence versus white-light bronchoscopy for detection of preneoplastic lesions: a randomized study. J Natl Cancer Inst 93: 1385-1391. doi:10.1093/jnci/93.18.1385

Hodgkinson CL, Morrow CJ, Li Y, Metcalf RL, Rothwell DG, Trapani F, Polanski R, Burt DJ, Simpson KL, Morris K, et al. 2014. Tumorigenicity and genetic profiling of circulating tumor cells in small-cell lung cancer. Nat Med 20: 897-903. doi:10.1038/nm.3600

Hofman V, Bonnetaud C, Ilie MI, Vielh P, Vignaud JM, Fléjou JF, Lantuejoul S, Piaton E, Mourad N, Butori C, et al. 2011. Preoperative circulating tumor cell detection using the isolation by size of epithelial tumor cell method for patients with lung cancer is a new prognostic bio- 
marker. Clin Cancer Res 17: 827-835. doi:10.1158/10780432.CCR-10-0445

Hofman P, Heeke S, Alix-Panabières C, Pantel K. 2019. Liquid biopsy in the era of immuno-oncology: is it ready for prime-time use for cancer patients? Ann Oncol 30: 14481459. doi:10.1093/annonc/mdz196

Hou JM, Greystoke A, Lancashire L, Cummings J, Ward T, Board R, Amir E, Hughes S, Krebs M, Hughes A, et al. 2009. Evaluation of circulating tumor cells and serological cell death biomarkers in small cell lung cancer patients undergoing chemotherapy. Am J Pathol 175: 808-816. doi:10.2353/ajpath.2009.090078

Hou JM, Krebs MG, Lancashire L, Sloane R, Backen A, Swain RK, Priest LJC, Greystoke A, Zhou C, Morris K, et al. 2012. Clinical significance and molecular characteristics of circulating tumor cells and circulating tumor microemboli in patients with small-cell lung cancer. J Clin Oncol 30: 525-532.

Hu X, Fujimoto J, Ying L, Fukuoka J, Ashizawa K, Sun W, Reuben A, Chow CW, McGranahan N, Chen R, et al 2019. Multi-region exome sequencing reveals genomic evolution from preneoplasia to lung adenocarcinoma. Nat Commun 10: 2978. doi:10.1038/s41467-019-10877-8

Hulbert A, Jusue-Torres I, Stark A, Chen C, Rodgers K, Lee B, Griffin C, Yang A, Huang P, Wrangle J, et al. 2017. Early detection of lung cancer using DNA promoter hypermethylation in plasma and sputum. Clin Cancer Res 23: 1998-2005. doi:10.1158/1078-0432.CCR-16-1371

Hussenet T, Dali S, Exinger J, Monga B, Jost B, Dembelé D, Martinet N, Thibault C, Huelsken J, Brambilla E, et al. 2010. SOX2 is an oncogene activated by recurrent $3 q 26.3$ amplifications in human lung squamous cell carcinomas. PLOS ONE 5: e8960. doi:10.1371/journal.pone.0008960

Ilié M, Szafer-Glusman E, Hofman V, Chamorey E, Lalvée S, Selva E, Leroy S, Marquette CH, Kowanetz M, Hedge P, et al. 2018. Detection of PD-L1 in circulating tumor cells and white blood cells from patients with advanced nonsmall-cell lung cancer. Ann Oncol 29: 193-199. doi:10 $.1093 / \mathrm{annonc/mdx636}$

Integrative Analysis of Lung Cancer Etiology and Risk (INTEGRAL) Consortium for Early Detection of Lung Cancer; Guida F, Sun N, Bantis LE, Muller DC, Li P, Taguchi A, Dhillon D, Kundnani DL, Patel NJ, et al. 2018. Assessment of lung cancer risk on the basis of a biomarker panel of circulating proteins. JAMA Oncol 4: e182078. doi:10 .1001/jamaoncol.2018.2078

Izumchenko E, Chang X, Brait M, Fertig E, Kagohara LT, Bedi A, Marchionni L, Agrawal N, Ravi R, Jones S, et al. 2015. Targeted sequencing reveals clonal genetic changes in the progression of early lung neoplasms and paired circulating DNA. Nat Commun 6: 8258. doi:10.1038/ ncomms9258

Kadara H, Scheet P, Wistuba II, Spira AE. 2016. Early events in the molecular pathogenesis of lung cancer. Cancer Prev Res (Phila) 9: 518-527. doi:10.1158/1940-6207.CAPR15-0400

Kadara H, Sivakumar S, Jakubek Y, San Lucas FA, Lang W, McDowell T, Weber Z, Behrens C, Davies GE, Kalhor N, et al. 2019. Driver mutations in normal airway epithelium elucidate spatiotemporal resolution of lung cancer. $\mathrm{Am} \mathrm{J}$ Respir Crit Care Med 200: 742-750. doi:10.1164/rccm .201806-1178OC
Kallergi G, Vetsika EK, Aggouraki D, Lagoudaki E, Koutsopoulos A, Koinis F, Katsarlinos P, Trypaki M, Messaritakis I, Stournaras C, et al. 2018. Evaluation of PD-L1/PD-1 on circulating tumor cells in patients with advanced nonsmall cell lung cancer. Ther $A d v$ Med Oncol 10: 175883401775012. doi:10.1177/1758834017750121

Kang S, Li Q, Chen Q, Zhou Y, Park S, Lee G, Grimes B, Krysan K, Yu M, Wang W, et al. 2017. Cancerlocator: non-invasive cancer diagnosis and tissue-of-origin prediction using methylation profiles of cell-free DNA. Genome Biol 18: 53. doi:10.1186/s13059-017-1191-5

Kapeleris J, Kulasinghe A, Warkiani ME, Vela I, Kenny L, O’Byrne K, Punyadeera C. 2018. The prognostic role of circulating tumor cells (CTCs) in lung cancer. Front Oncol 8: 311. doi:10.3389/fonc.2018.00311

Katki HA, Kovalchik SA, Berg CD, Cheung LC, Chaturvedi AK. 2016. Development and validation of risk models to select ever-smokers for CT lung cancer screening. JAMA 315: 2300-2311. doi:10.1001/jama.2016.6255

Katki HA, Kovalchik SA, Petito LC, Cheung LC, Jacobs E, Jemal A, Berg CD, Chaturvedi AK. 2018. Implications of nine risk prediction models for selecting ever-smokers for computed tomography lung cancer screening. Ann Intern Med 169: 10-19. doi:10.7326/M17-2701

Keith RL, Miller YE, Gemmill RM, Drabkin HA, Dempsey EC, Kennedy TC, Prindiville S, Franklin WA. 2000. Angiogenic squamous dysplasia in bronchi of individuals at high risk for lung cancer. Clin Cancer Res 6: 1616-1625.

Kitamura H, Kameda Y, Ito T, Hayashi H. 1999. Atypical adenomatous hyperplasia of the lung: implications for the pathogenesis of peripheral lung adenocarcinoma. Am J Clin Pathol 111: 610-622. doi:10.1093/ajcp/111.5.610

Kolinsky MP, Stoecklein N, Lambros M, Gil V, Rodrigues DN, Carreira S, Zafeiriou Z, de Bono JS. 2020. Genetic analysis of circulating tumour cells. Recent Results Cancer Res 215: 57-76. doi:10.1007/978-3-030-26439-0_3

Krebs MG, Sloane R, Priest L, Lancashire L, Hou JM, Greystoke A, Ward TH, Ferraldeschi R, Hughes A, Clack G, et al. 2011. Evaluation and prognostic significance of circulating tumor cells in patients with non-small-cell lung cancer. J Clin Oncol 29: 1556-1563. doi:10.1200/JCO .2010.28.7045

Krebs MG, Hou JM, Sloane R, Lancashire L, Priest L, Nonaka D, Ward TH, Backen A, Clack G, Hughes A, et al. 2012. Analysis of circulating tumor cells in patients with nonsmall cell lung cancer using epithelial marker-dependent and -independent approaches. J Thorac Oncol 7: 306-315. doi:10.1097/JTO.0b013e31823c5c16

Krysan K, Tran LM, Grimes BS, Fishbein GA, Seki A, Gardner BK, Walser TC, Salehi-Rad R, Yanagawa J, Lee JM, et al. 2019. The immune contexture associates with the genomic landscape in lung adenomatous premalignancy. Cancer Res 79: 5022-5033.

Kuske A, Gorges TM, Tennstedt P, Tiebel AK, Pompe R, Preißer F, Prues S, Mazel M, Markou A, Lianidou E, et al. 2016. Improved detection of circulating tumor cells in non-metastatic high-risk prostate cancer patients. Sci Rep 6: 39736 . doi:10.1038/srep39736

Kwon MC, Berns A. 2013. Mouse models for lung cancer. Mol Oncol 7: 165-177. doi:10.1016/j.molonc.2013.02.010

Lamy A, Sesboüé R, Bourguignon J, Dautréaux B, Métayer J, Frébourg T, Thiberville L. 2002. Aberrant methylation of 
H. Kadara et al.

the CDKN2a/p16INK4a gene promoter region in preinvasive bronchial lesions: a prospective study in high-risk patients without invasive cancer. Int J Cancer 100: 189193. doi:10.1002/ijc.10474

Larsen JE, Nathan V, Osborne JK, Farrow RK, Deb D, Sullivan JP, Dospoy PD, Augustyn A, Hight SK, Sato M, et al 2016. ZEB1 drives epithelial-to-mesenchymal transition in lung cancer. J Clin Invest 126: 3219-3235. doi:10.1172/ JCI76725

Lavin Y, Kobayashi S, Leader A, Amir ED, Elefant N, Bigenwald C, Remark R, Sweeney R, Becker CD, Levine JH, et al. 2017. Innate immune landscape in early lung adenocarcinoma by paired single-cell analyses. Cell 169: 750765.e17. doi:10.1016/j.cell.2017.04.014

Lechner JF, Haugen A, Autrup H, McClendon IA, Trump BF, Harris CC. 1981. Clonal growth of epithelial cells from normal adult human bronchus. Cancer Res 41: $2294-$ 2304.

Leng S, Wu G, Klinge DM, Thomas CL, Casas E, Picchi MA, Stidley CA, Lee SJ, Aisner S, Siegfried JM, et al. 2017. Gene methylation biomarkers in sputum as a classifier for lung cancer risk. Oncotarget 8: 63978-63985. doi:10.18632/on cotarget. 19255

Li J, Shi SB, Shi WL, Wang Y, Yu LC, Zhu LR, Ge LP. 2014. LUNX mRNA-positive cells at different time points predict prognosis in patients with surgically resected nonsmall cell lung cancer. Transl Res 163:27-35. doi:10.1016/ j.trsl.2013.09.010

Liang H, Huang J, Wang B, Liu Z, He J, Liang W. 2018. The role of liquid biopsy in predicting post-operative recurrence of non-small cell lung cancer. J Thorac Dis 10: S838-S845. doi:10.21037/jtd.2018.04.08

Lim SB, Yeo T, Lee WD, Bhagat AAS, Tan SJ, Tan DSW, Lim WT, Lim CT. 2019. Addressing cellular heterogeneity in tumor and circulation for refined prognostication. Proc Natl Acad Sci 116: 17957-17962. doi:10.1073/pnas 1907904116

Lin PP, Gires O, Wang DD, Li L, Wang H. 2017. Comprehensive in situ co-detection of aneuploid circulating endothelial and tumor cells. Sci Rep 7: 9789. doi:10.1038/ s41598-017-10763-7

Liu L, Liao GQ, He P, Zhu H, Liu PH, Qu YM, Song XM, Xu QW, Gao Q, Zhang Y, et al. 2008. Detection of circulating cancer cells in lung cancer patients with a panel of marker genes. Biochem Biophys Res Commun 372: 756-760. doi:10.1016/j.bbrc.2008.05.101

Lu Y, Futtner C, Rock JR, Xu X, Whitworth W, Hogan BL, Onaitis MW. 2010. Evidence that SOX2 overexpression is oncogenic in the lung. PLoS ONE 5: e11022. doi:10.1371/ journal.pone.0011022

Luskin MR, Murakami MA, Manalis SR, Weinstock DM. 2018. Targeting minimal residual disease: a path to cure? Nat Rev Cancer 18: 255-263. doi:10.1038/nrc .2017 .125

Markou A, Lazaridou M, Paraskevopoulos P, Chen S, Świerczewska M, Budna J, Kuske A, Gorges TM, Joosse SA, Kroneis T, et al. 2018. Multiplex gene expression profiling of in vivo isolated circulating tumor cells in high-risk prostate cancer patients. Clin Chem 64: 297-306. doi:10 $.1373 /$ clinchem.2017.275503

Mascaux C, Angelova M, Vasaturo A, Beane J, Hijazi K, Anthoine G, Buttard B, Rothe F, Willard-Gallo K, Haller
A, et al. 2019. Immune evasion before tumour invasion in early lung squamous carcinogenesis. Nature 571: 570575. doi:10.1038/s41586-019-1330-0

Matthew EM, Zhou L, Yang Z, Dicker DT, Holder SL, Lim B, Harouaka R, Zheng SY, Drabick JJ, Lamparella NE, et al. 2016. A multiplexed marker-based algorithm for diagnosis of carcinoma of unknown primary using circulating tumor cells. Oncotarget 7: 3662-3676. doi:10.18632/onco target.6657

McCaughan F, Pole JC, Bankier AT, Konfortov BA, Carroll B, Falzon M, Rabbitts TH, George PJ, Der PH, Rabbitts PH. 2010. Progressive 3q amplification consistently targets SOX2 in preinvasive squamous lung cancer. $A m$ Respir Crit Care Med 182: 83-91. doi:10.1164/rccm .201001-0005OC

Merrick DT, Haney J, Petrunich S, Sugita M, Miller YE, Keith RL, Kennedy TC, Franklin WA. 2005. Overexpression of vascular endothelial growth factor and its receptors in bronchial dypslasia demonstrated by quantitative RT-PCR analysis. Lung Cancer 48: 31-45. doi:10.1016/j .lungcan.2004.07.049

Meuwissen R, Berns A. 2005. Mouse models for human lung cancer. Genes Dev 19: 643-664. doi:10.1101/gad.1284505

Milette S, Fiset PO, Walsh LA, Spicer JD, Quail DF. 2019. The innate immune architecture of lung tumors and its implication in disease progression. J Pathol 247: 589-605. doi:10.1002/path.5241

Muinelo-Romay L, Vieito M, Abalo A, Nocelo MA, Barón F, Anido U, Brozos E, Vázquez F, Aguín S, Abal M, et al. 2014. Evaluation of circulating tumor cells and related events as prognostic factors and surrogate biomarkers in advanced NSCLC patients receiving first-line systemic treatment. Cancers (Basel) 6: 153-165. doi:10.3390/can cers6010153

Mukhopadhyay A, Berrett KC, Kc U, Clair PM, Pop SM, Carr SR, Witt BL, Oliver TG. 2014. Sox 2 cooperates with Lkb1 loss in a mouse model of squamous cell lung cancer. Cell Rep 8: 40-49. doi:10.1016/j.celrep.2014 .05 .036

Naito T, Tanaka F, Ono A, Yoneda K, Takahashi T, Murakami H, Nakamura Y, Tsuya A, Kenmotsu H, Shukuya T, et al. 2012. Prognostic impact of circulating tumor cells in patients with small cell lung cancer. $J$ Thorac Oncol 7: 512-519. doi:10.1097/JTO.0b013e31823f125d

Nakanishi K, Kawai T, Kumaki F, Hiroi S, Mukai M, Ikeda E. 2003. Survivin expression in atypical adenomatous hyperplasia of the lung. Am J Clin Pathol 120: 712-719. doi:10.1309/GWTN2JTAN6K73YDE

National Lung Screening Trial Research Team; Aberle DR, Berg CD, Black WC, Church TR, Fagerstrom RM, Galen B, Gareen IF, Gatsonis C, Goldin J, et al. 2011a. The National Lung Screening Trial: overview and study design. Radiology 258: 243-253. doi:10.1148/radiol.100 91808

National Lung Screening Trial Research Team; Aberle DR, Adams AM, Berg CD, Black WC, Clapp JD, Fagerstrom RM, Gareen IF, Gatsonis C, Marcus PM, et al. 2011b. Reduced lung-cancer mortality with low-dose computed tomographic screening. N Engl J Med 365: 395-409. doi:10.1056/NEJMoa1102873

Nicolazzo C, Raimondi C, Mancini M, Caponnetto S, Gradilone A, Gandini O, Mastromartino M, Del Bene G, 
Prete A, Longo F, et al. 2016. Monitoring PD-L1 positive circulating tumor cells in non-small cell lung cancer patients treated with the PD-1 inhibitor nivolumab. Sci Rep 6: 31726 . doi:10.1038/srep31726

Normanno N, Rossi A, Morabito A, Signoriello S, Bevilacqua S, Di Maio M, Costanzo R, De Luca A, Montanino A, Gridelli C, et al. 2014. Prognostic value of circulating tumor cells' reduction in patients with extensive smallcell lung cancer. Lung Cancer 85: 314-319. doi:10.1016/j .lungcan.2014.05.002

Oken MM, Hocking WG, Kvale PA, Andriole GL, Buys SS, Church TR, Crawford ED, Fouad MN, Isaacs C, Reding DJ, et al. 2011. Screening by chest radiograph and lung cancer mortality: the prostate, lung, colorectal, and ovarian (PLCO) randomized trial. JAMA 306: 1865-1873. doi:10.1001/jama.2011.1591

Olson B, Li Y, Lin Y, Liu ET, Patnaik A. 2018. Mouse models for cancer immunotherapy research. Cancer Discov 8: 1358-1365. doi:10.1158/2159-8290.CD-18-0044

Pantel K, Alix-Panabières C. 2019. Liquid biopsy and minimal residual disease-latest advances and implications for cure. Nat Rev Clin Oncol 16: 409-424. doi:10.1038/ s41571-019-0187-3

Pailler E, Oulhen M, Borget I, Remon J, Ross K, Auger N, Billiot F, Ngo Camus M, Commo F, Lindsay CR, et al. 2017. Circulating tumor cells with aberrant ALK copy number predict progression-free survival during crizotinib treatment in ALK-rearranged non-small cell lung cancer patients. Cancer Res 77: 2222-2230. doi:10.1158/ 0008-5472.CAN-16-3072

Peeters DJ, De Laere B, Van den Eynden GG, Van Laere SJ, Rothé F, Ignatiadis M, Sieuwerts AM, Lambrechts D, Rutten A, van Dam PA, et al. 2013. Semiautomated isolation and molecular characterisation of single or highly purified tumour cells from cellSearch enriched blood samples using dielectrophoretic cell sorting. Br J Cancer 108: $1358-$ 1367. doi:10.1038/bjc. 2013.92

Pham D, Bhandari S, Oechsli M, Pinkston CM, Kloecker GH. 2018. Lung cancer screening rates: data from the lung cancer screening registry. J Clin Oncol 36: 6504. doi:10.1200/JCO.2018.36.15_suppl.6504

Pio R, Garcia J, Corrales L, Ajona D, Fleischhacker M, Pajares MJ, Cardenal F, Seijo L, Zulueta JJ, Nadal E, et al. 2010. Complement factor $\mathrm{H}$ is elevated in bronchoalveolar lavage fluid and sputum from patients with lung cancer. Cancer Epidemiol Biomarkers Prev 19: 2665-2672. doi:10.1158/1055-9965.EPI-10-0467

Piyathilake CJ, Frost AR, Manne U, Weiss H, Heimburger DC, Grizzle WE. 2003. Nuclear accumulation of p53 is a potential marker for the development of squamous cell lung cancer in smokers. Chest 123: 181-186. doi:10.1378/ chest.123.1.181

Punnoose EA, Atwal S, Liu W, Raja R, Fine BM, Hughes BG, Hicks RJ, Hampton GM, Amler LC, Pirzkall A, et al. 2012. Evaluation of circulating tumor cells and circulating tumor DNA in non-small cell lung cancer: association with clinical endpoints in a phase II clinical trial of pertuzumab and erlotinib. Clin Cancer Res 18: 2391-2401. doi:10 .1158/1078-0432.CCR-11-3148

Ramirez RD, Sheridan S, Girard L, Sato M, Kim Y, Pollack J, Peyton M, Zou Y, Kurie JM, Dimaio JM, et al. 2004. Immortalization of human bronchial epithelial cells in the absence of viral oncoproteins. Cancer Res 64: 90279034. doi:10.1158/0008-5472.CAN-04-3703

Reddel RR, Ke Y, Gerwin BI, McMenamin MG, Lechner JF, Su RT, Brash DE, Park JB, Rhim JS, Harris CC. 1988. Transformation of human bronchial epithelial cells by infection with SV40 or adenovirus-12 SV40 hybrid virus, or transfection via strontium phosphate coprecipitation with a plasmid containing SV40 early region genes. Cancer Res 48: 1904-1909.

Reddel RR, Salghetti SE, Willey JC, Ohnuki Y, Ke Y, Gerwin BI, Lechner JF, Harris CC. 1993. Development of tumorigenicity in simian virus 40 -immortalized human bronchial epithelial cell lines. Cancer Res 53: 985-991.

Riethdorf S, Fritsche H, Muller V, Rau T, Schindlbeck C, Rack B, Müller V, Rau T, Schindlbeck C, Rack B, et al. 2007. Detection of circulating tumor cells in peripheral blood of patients with metastatic breast cancer: a validation study of the CellSearch system. Clin Cancer Res 13: 920-928. doi:10.1158/1078-0432.CCR-06-1695

Rivera MP, Tanner NT, Silvestri GA, Detterbeck FC, Tammemägi MC, Young RP, Slatore CG, Caverly TJ, Boyd CM, Braithwaite D, et al. 2018. Incorporating coexisting chronic illness into decisions about patient selection for lung cancer screening. an official American thoracic society research statement. Am J Respir Crit Care Med 198: e3-e13. doi:10.1164/rccm.201805-0986ST

Rom WN, Hay JG, Lee TC, Jiang Y, Tchou-Wong KM. 2000. Molecular and genetic aspects of lung cancer. Am J Respir Crit Care Med 161: 1355-1367. doi:10.1164/ajrccm.161.4 .9908012

Rosenthal R, Cadieux EL, Salgado R, Bakir MA, Moore DA, Hiley CT, Lund T, Tanić M, Reading JL, Joshi K, et al. 2019. Neoantigen-directed immune escape in lung cancer evolution. Nature 567: 479-485. doi:10.1038/s41586019-1032-7

Rugo HS, Cortes J, Awada A, O'Shaughnessy J, Twelves C, Im SA, Hannah A, Lu L, Sy S, Caygill K, et al. 2018. Change in topoisomerase 1-positive circulating tumor cells affects overall survival in patients with advanced breast cancer after treatment with etirinotecan pegol. Clin Cancer Res 24: 3348-3357. doi:10.1158/1078-0432 .CCR-17-3059

Sasai K, Sukezane T, Yanagita E, Nakagawa H, Hotta A, Itoh T, Akagi T. 2011. Oncogene-mediated human lung epithelial cell transformation produces adenocarcinoma phenotypes in vivo. Cancer Res 71: 2541-2549. doi:10 .1158/0008-5472.CAN-10-2221

Sato M, Vaughan MB, Girard L, Peyton M, Lee W, Shames DS, Ramirez RD, Sunaga N, Gazdar AF, Shay JW, et al. 2006. Multiple oncogenic changes (K-RAS(V12), p53 knockdown, mutant EGFRs, p16 bypass, telomerase) are not sufficient to confer a full malignant phenotype on human bronchial epithelial cells. Cancer Res 66: 2116-2128. doi:10.1158/0008-5472.CAN-05-2521

Sato M, Larsen JE, Lee W, Sun H, Shames DS, Dalvi MP, Ramirez RD, Tang H, DiMaio JM, Gao B, et al. 2013. Human lung epithelial cells progressed to malignancy through specific oncogenic manipulations. Mol Cancer Res 11: 638-650. doi:10.1158/1541-7786.MCR-12-06 34- $\mathrm{T}$

Seijo LM, Peled N, Ajona D, Boeri M, Field JK, Sozzi G, Pio R, Zulueta JJ, Spira A, Massion PP, et al. 2019. Biomarkers 
H. Kadara et al.

in lung cancer screening: achievements, promises, and challenges. J Thorac Oncol 14: 343-357. doi:10.1016/j .jtho.2018.11.023

Shen SY, Singhania R, Fehringer G, Chakravarthy A, Roehrl MHA, Chadwick D, Zuzarte PC, Borgida A, Wang TT, Li T, et al. 2018. Sensitive tumour detection and classification using plasma cell-free DNA methylomes. Nature 563: 579-583. doi:10.1038/s41586-018-0703-0

Sher YP, Shih JY, Yang PC, Roffler SR, Chu YW, Wu CW, Yu CL, Peck K. 2005. Prognosis of non-small cell lung cancer patients by detecting circulating cancer cells in the peripheral blood with multiple marker genes. Clin Cancer Res 11: 173-179.

Sienel W, Seen-Hibler R, Mutschler W, Pantel K, Passlick B. 2003. Tumour cells in the tumour draining vein of patients with non-small cell lung cancer: detection rate and clinical significance. Eur J Cardiothorac Surg 23: 451-456. doi:10.1016/S1010-7940(02)00865-5

Sigal A, Rotter V. 2000. Oncogenic mutations of the p53 tumor suppressor: the demons of the guardian of the genome. Cancer Res 60: 6788-6793.

Sivakumar S, Lucas FAS, McDowell TL, Lang W, Xu L, Fujimoto J, Zhang J, Futreal PA, Fukuoka J, Yatabe Y, et al. 2017. Genomic landscape of atypical adenomatous hyperplasia reveals divergent modes to lung adenocarcinoma. Cancer Res 77: 6119-6130. doi:10.1158/0008-5472 CAN-17-1605

Spira A, Yurgelun MB, Alexandrov L, Rao A, Bejar R, Polyak K, Giannakis M, Shilatifard A, Finn OJ, Dhodapkar M, et al. 2017. Precancer atlas to drive precision prevention trials. Cancer Res 77: 1510-1541. doi:10.1158/00085472.CAN-16-2346

Sun B, Wang H, Wang X, Huang H, Ding W, Jing R, Shi G, Zhu L. 2009. A proliferation-inducing ligand: a new biomarker for non-small cell lung cancer. Exp Lung Res 35: 486-500. doi:10.1080/01902140902759274

Takamochi K, Ogura T, Suzuki K, Kawasaki H, Kurashima Y, Yokose T, Ochiai A, Nagai K, Nishiwki Y, Esumi H. 2001. Loss of heterozygosity on chromosomes $9 q$ and $16 p$ in atypical adenomatous hyperplasia concomitant with adenocarcinoma of the lung. Am J Pathol 159: 1941-1948. doi:10.1016/S0002-9440(10)63041-6

Tammemägi MC, Katki HA, Hocking WG, Church TR, Caporaso N, Kvale PA, Chaturvedi AK, Silvestri GA, Riley TL, Commins J, et al. 2013. Selection criteria for lungcancer screening. $N$ Engl J Med 368: 728-736. doi:10 .1056/NEJMoa1211776

Tammemägi MC, Schmidt H, Martel S, McWilliams A, Goffin JR, Johnston MR, Nicholas G, Tremblay A, Bhatia R, Liu G, et al. 2017. Participant selection for lung cancer screening by risk modelling (the Pan-Canadian Early Detection Of Lung Cancer [PanCan] study): a single-arm, prospective study. Lancet Oncol 18: 1523-1531. doi:10 .1016/S1470-2045(17)30597-1

Tanoue LT, Tanner NT, Gould MK, Silvestri GA. 2015. Lung cancer screening. Am J Respir Crit Care Med 191: 19-33. doi:10.1164/rccm.201410-1777CI

Tellez CS, Juri DE, Do K, Bernauer AM, Thomas CL, Damiani LA, Tessema M, Leng S, Belinsky SA. 2011 EMT and stem cell-like properties associated with miR205 and miR-200 epigenetic silencing are early manifestations during carcinogen-induced transformation of hu- man lung epithelial cells. Cancer Res 71: 3087-3097. doi:10.1158/0008-5472.CAN-10-3035

Tellez CS, Juri DE, Do K, Picchi MA, Wang T, Liu G, Spira A, Belinsky SA. 2016. miR-196b is epigenetically silenced during the premalignant stage of lung carcinogenesis. Cancer Res 76: 4741-4751. doi:10.1158/0008-5472 .CAN-15-3367

Tichelaar JW, Zhang Y, leRiche JC, Biddinger PW, Lam S, Anderson MW. 2005. Increased staining for phosphoAkt, p65/RELA and cIAP-2 in pre-neoplastic human bronchial biopsies. BMC Cancer 5: 155. doi:10.1186/ 1471-2407-5-155

Tominaga M, Sueoka N, Irie K, Iwanaga K, Tokunaga O, Hayashi S, Nakachi K, Sueoka E. 2003. Detection and discrimination of preneoplastic and early stages of lung adenocarcinoma using hnRNP B1 combined with the cell cycle-related markers p16, cyclin D1, and Ki-67. Lung Cancer 40: 45-53. doi:10.1016/S0169-5002(02)00529-9

Tsao AS, McDonnell T, Lam S, Putnam JB, Bekele N, Hong WK, Kurie JM. 2003. Increased phospho-AKT $\left(\mathrm{Ser}^{473}\right)$ expression in bronchial dysplasia: implications for lung cancer prevention studies. Cancer Epidemiol Biomarkers Prev 12: 660-664.

Vachani A, Sequist LV, Spira A. 2017. AJRCCM: 100-year anniversary. The shifting landscape for lung cancer: past, present, and future. Am J Respir Crit Care Med 195: 1150 1160. doi:10.1164/rccm.201702-0433CI

Vona G, Sabile A, Louha M, Sitruk V, Romana S, Schütze K, Capron F, Franco D, Pazzagli M, Vekemans M, et al. 2000. Isolation by size of epithelial tumor cells: a new method for the immunomorphological and molecular characterization of circulating tumor cells. Am J Pathol 156: 57-63. doi:10.1016/S0002-9440(10)64706-2

Walser TC, Jing Z, Tran LM, Lin YQ, Yakobian N, Wang G, Krysan K, Zhu LX, Sharma S, Lee MH, et al. 2018. Silencing the snail-dependent RNA splice regulator ESRP1 drives malignant transformation of human pulmonary epithelial cells. Cancer Res 78: 1986-1999. doi:10.1158/ 0008-5472.CAN-17-0315

Wang Y, Midthun DE, Wampfler JA, Deng B, Stoddard SM, Zhang S, Yang P. 2015. Trends in the proportion of patients with lung cancer meeting screening criteria. JAMA 313: 853-855. doi:10.1001/jama.2015.413

Weitz J, Kienle P, Lacroix J, Willeke F, Benner A, Lehnert T, Herfarth C, von Knebel Doeberitz M. 1998. Dissemination of tumor cells in patients undergoing surgery for colorectal cancer. Clin Cancer Res 4: 343-348.

Westra WH. 2000. Early glandular neoplasia of the lung. Respir Res 1: 163-169. doi:10.1186/rr28

Westra WH, Slebos RJ, Offerhaus GJ, Goodman SN, Evers SG, Kensler TW, Askin FB, Rodenhuis S, Hruban RH. 1993. K-ras oncogene activation in lung adenocarcinomas from former smokers. Evidence that K-ras mutations are an early and irreversible event in the development of adenocarcinoma of the lung. Cancer 72: 432-438. doi:10 .1002/1097-0142(19930715)72:2<432::AID-CNCR28207 20219>3.0.CO;2-\#

Wiedenfeld EA, Fernandez-Vina M, Berzofsky JA, Carbone DP. 1994. Evidence for selection against human lung cancers bearing p53 missense mutations which occur within the HLA A*0201 peptide consensus motif. Cancer Res 54: $1175-1177$. 
Wilson JMG, Jungner G. 1968. Principles and practice of screening for disease. Public Health Papers, No. 241968, World Health Organization, Geneva.

Winer-Jones JP, Vahidi B, Arquilevich N, Fang C, Ferguson S, Harkins D, Hill C, Klem E, Pagano PC, Peasley C, et al. 2014. Circulating tumor cells: clinically relevant molecular access based on a novel CTC flow cell. PLOS ONE 9: e86717. doi:10.1371/journal.pone.0086717

Wistuba II, Gazdar AF. 2006. Lung cancer preneoplasia. Annu Rev Pathol 1: 331-348. doi:10.1146/annurev .pathol.1.110304.100103

Wistuba II, Lam S, Behrens C, Virmani AK, Fong KM, LeRiche J, Samet JM, Srivastava S, Minna JD, Gazdar AF. 1997. Molecular damage in the bronchial epithelium of current and former smokers. J Natl Cancer Inst 89: 1366-1373. doi:10.1093/jnci/89.18.1366

Wistuba II, Behrens C, Milchgrub S, Bryant D, Hung J, Minna JD, Gazdar AF. 1999. Sequential molecular abnormalities are involved in the multistage development of squamous cell lung carcinoma. Oncogene 18: 643-650. doi:10.1038/sj.onc.1202349

Wistuba II, Behrens C, Virmani AK, Mele G, Milchgrub S, Girard L, Fondon JW III, Garner HR, McKay B, Latif F, et al. 2000. High resolution chromosome $3 p$ allelotyping of human lung cancer and preneoplastic/preinvasive bronchial epithelium reveals multiple, discontinuous sites of $3 \mathrm{p}$ allele loss and three regions of frequent breakpoints. Cancer Res 60: 1949-1960.

Xiang R, Liao D, Cheng T, Zhou H, Shi Q, Chuang TS, Markowitz D, Reisfeld RA, Luo Y. 2011. Downregulation of transcription factor SOX2 in cancer stem cells suppresses growth and metastasis of lung cancer. $\mathrm{Br} \mathrm{J}$ Cancer 104: 1410-1417. doi:10.1038/bjc.2011.94

Yamashita J, Matsuo A, Kurusu Y, Saishoji T, Hayashi N, Ogawa M. 2002. Preoperative evidence of circulating tumor cells by means of reverse transcriptase-polymerase chain reaction for carcinoembryonic antigen messenger RNA is an independent predictor of survival in non-small cell lung cancer: a prospective study. $J$ Thorac Cardiovasc Surg 124: 299-305. doi:10.1067/mtc.2002.124370
Yatabe Y. 2010. EGFR mutations and the terminal respiratory unit. Cancer Metastasis Rev 29: 23-36. doi:10.1007/ s10555-010-9205-8

Yatabe Y, Mitsudomi T, Takahashi T. 2002. TTF-1 expression in pulmonary adenocarcinomas. Am J Surg Pathol 26: 767-773. doi:10.1097/00000478-200206000-00010

Yie SM, Lou B, Ye SR, He X, Cao M, Xie K, Ye NY, Lin R, Wu SM, Xiao HB, et al. 2009. Clinical significance of detecting survivin-expressing circulating cancer cells in patients with non-small cell lung cancer. Lung Cancer 63: 284290. doi:10.1016/j.lungcan.2008.05.024

Yoon SO, Kim YT, Jung KC, Jeon YK, Kim BH, Kim CW. 2011. TTF-1 mRNA-positive circulating tumor cells in the peripheral blood predict poor prognosis in surgically resected non-small cell lung cancer patients. Lung Cancer 71: 209-216. doi:10.1016/j.lungcan.2010.04.017

Yuan P, Kadara H, Behrens C, Tang X, Woods D, Solis LM, Huang J, Spinola M, Dong W, Yin G, et al. 2010. Sex determining region Y-Box 2 (SOX2) is a potential celllineage gene highly expressed in the pathogenesis of squamous cell carcinomas of the lung. PLoS ONE 5: e9112. doi:10.1371/journal.pone.0009112

Zhang J, Wang HT, Li BG. 2014a. Prognostic significance of circulating tumor cells in small-cell lung cancer patients: a meta-analysis. Asian Pac J Cancer Prev 15: 8429-8433. doi:10.7314/APJCP.2014.15.19.8429

Zhang Z, Shiratsuchi H, Lin J, Chen G, Reddy RM, Azizi E, Fouladdel S, Chang AC, Lin L, Jiang H, et al. 2014b. Expansion of CTCs from early stage lung cancer patients using a microfluidic co-culture model. Oncotarget 5: 12383-12397. doi:10.18632/oncotarget.2592

Zhang Z, Xiao Y, Zhao J, Chen M, Xu Y, Zhong W, Xiang J, Wang M. 2016. Relationship between circulating tumour cell count and prognosis following chemotherapy in patients with advanced non-small-cell lung cancer. Respirology 21: 519-525. doi:10.1111/resp.12696

Zi Z, Zhang Y, Zhang P, Ding Q, Chu M, Chen Y, Minna JD, Yu Y. 2020. A proteomic connectivity map for characterizing the tumor adaptive response to small molecule chemical perturbagens. ACS Chem Biol 15: 140-150. doi:10.1021/acschembio.9b00694 


\section{$\&_{\mathrm{CSH}}^{\infty} \&$ Cold Spring Harbor

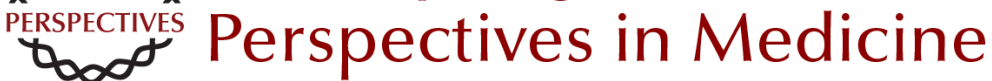

\section{Early Diagnosis and Screening for Lung Cancer}

Humam Kadara, Linh M. Tran, Bin Liu, Anil Vachani, Shuo Li, Ansam Sinjab, Xianghong J. Zhou, Steven M. Dubinett and Kostyantyn Krysan

Cold Spring Harb Perspect Med 2021; doi: 10.1101/cshperspect.a037994 originally published online May 17,2021

Subject Collection Lung Cancer: Disease Biology and Its Potential for Clinical Translation

\author{
Tumor Immunology and Immunotherapy of \\ Non-Small-Cell Lung Cancer \\ Tina Cascone, Jared Fradette, Monika Pradhan, et \\ al. \\ Molecular Pathology of Lung Cancer \\ James J. Saller and Theresa A. Boyle
Preclinical Models for the Study of Lung Cancer
Pathogenesis and Therapy Development
Anna Arnal-Estapé, Giorgia Foggetti, Jacqueline $H$. Starrett, et al. \\ Radiation Therapy in Non-Small-Cell Lung Cancer \\ Michael Dohopolski, Sujana Gottumukkala, Daniel \\ Gomez, et al.

\section{Application of Radiomics and Artificial \\ Intelligence for Lung Cancer Precision Medicine \\ Ilke Tunali, Robert J. Gillies and Matthew B.} \\ Schabath \\ Advances in Small-Cell Lung Cancer (SCLC) \\ Translational Research \\ Benjamin J. Drapkin and Charles M. Rudin
}

\author{
Lung Cancer Stem Cells and Their Clinical \\ Implications \\ Samuel P. Rowbotham, Mounika U.L. Goruganthu, \\ Rajeswara R. Arasada, et al.
Lung Cancer Computational Biology and
Resources \\ Ling Cai, Guanghua Xiao, David Gerber, et al. \\ Metabolic Phenotypes, Dependencies, and \\ Adaptation in Lung Cancer \\ Gina M. DeNicola and David B. Shackelford
Early Diagnosis and Screening for Lung Cancer Humam Kadara, Linh M. Tran, Bin Liu, et al.
Targeting Epigenetics in Lung Cancer Yvonne L. Chao and Chad V. Pecot

